\title{
Implikasi Teologis Makna Peristiwa Pentakosta Dalam Kisah Para Rasul 2: 1-13
}

\author{
Daido Tri Sampurna Lumbanraja \\ Institut Agama Kristen Negeri Palangka Raya \\ daidolumbanraja@gmail.com
}

\begin{abstract}
Naturally the discussion about the Spirit leads to the book of Acts which is the basis of the Baptism of the Holy Spirit by the Pentecostal school. As Pentecostalism developed, advocates emerged as people who were trained theologically, so that the discussion became moreweighty with the consensus that the interpretation of Acts must be carried out responsibly by applying correct hermeneutic principles. The author is interested in delving deeper into the text about the Holy Spirit from the events of Pentecost, namely Acts 2: 1-13, by applying hermeneutic principles in an exegetical study. Therefore, this article uses a type of literature research to support exegetical studies of the text of Acts 2: 1-13. The results obtained were in the form of interpretations of the Pentecost event, namely: the moment of the outpouring of the Holy Spirit as the fulfillment of God's promise and the moment of the outpouring was the fulfillment of the promise regarding the Power of the Holy Spirit as empowerment to become a witness of Jesus Christ. This article also includes the theological implications of today's Pentecost events.
\end{abstract}

Keywords: holy spirit; pentecost; theological implications

\begin{abstract}
Abstrak
Secara natural diskusi mengenai Roh Kudus mengarah pada kitab Kisah Para Rasul yang menjadi landasan pengajaran tentang baptisan Roh Kudus oleh aliran Pentakosta. Seiring dengan berkembangnya aliran Pentakosta, bermunculan para advokat sebagai orang-orang yang terlatih secara teologis, sehingga diskusi menjadi lebih berbobot dengan adanya konsensus bahwa penafsiran Kisah Para Rasul, harus dilakukan secara bertanggung jawab dengan menerapkan prinsip-prinsip hermeneutik yang benar. Penulis tertarik untuk mengkaji lebih mendalam teks mengenai Roh Kudus dari peristiwa Pentakosta, yaitu Kisah Para Rasul 2: 1-13, dengan menerapkan prinsip-prinsip hermeneutik dalam suatu studi eksegesis. Dengan demikian artikel ini menggunakan jenis penelitian kepustakaan untuk mendukung studi eksegesis terhadap teks Kisah Para Rasul 2: 1-13. Hasil yang didapat berupa pemaknaan terhadap peristiwa Pentakosta, yaitu: momen pencurahan Roh Kudus sebagai penggenapan janji Allah dan momen pencurahan adalah penggenapan janji mengenai Kuasa Roh Kudus sebagai pemberdayaan untuk menjadi saksi Yesus Kristus. Artikel ini juga menyertakan implikasi teologis peristiwa Pentakosta pada masa sekarang.
\end{abstract}

Kata kunci: implikasi teologis; peristiwa pentakosta; roh kudus

\section{Pendahuluan}

Peristiwa Pentakosta yang kerap dikenal sebagai momen pencurahan Roh Kudus adalah salah satu fenomena yang spektakuler sepanjang sejarah Alkitab terkhusus dalam Perjanjian Baru, peristiwa ini memiliki kesan yang begitu menarik, sehingga sangat mudah untuk diingat. Roh Kudus yang dicurahkan pada saat itu telah mengubah hati para murid Yesus, menyertai dan memberikan semangat untuk memberitakan kabar 
keselamatan. Peristiwa Pentakosta yang tercatat di dalam Kisah Para Rasul merupakan rujukan dasar dari lahirnya gerakan Pentakosta di dunia (Cole, 2013).

Gerakan Pentakosta lahir di Amerika, yang saat ini sudah berkembang sampai ke seluruh dunia (Kalis \& Panjaitan, 2020). Gerakan ini menarik banyak orang untuk datang kepada Kristus dan mengalami baptisan Roh Kudus, dimana hal ini menjadi ciri khas pengajaran yang membedakan gerakan Pentakosta dengan aliran Kristen lainnya. Perkembangan gerakan Pentakosta ini sangat cepat, menjangkau hingga ke negaranegara dunia ketiga. Berdasarkan data pada tahun 2011 mengenai studi tentang kekristenan di seluruh belahan dunia, diperkirakan terdapat 279 juta orang Kristen dari aliran Pentakosta, yaitu 12,8\% dari seluruh populasi orang Kristen di dunia. Sebagian besar dari jumlah itu terdapat di sub-Sahara Afrika (44\%), Amerika (37\%) dan Asia Pasifik (16\%), dan aliran Pentakosta adalah aliran Kristen dengan jumlah jemaat terbanyak di dunia (Pew Research, 2011). Sekalipun gerakan Pentakosta sudah diterima sebagai gerakan yang sah dalam kekristenan, namun masih ada saja usaha pembuktian dari berbagai kelompok yang menyatakan bahwa ciri khas yang dipegang oleh gerakan Pentakosta khususnya mengenai baptisan Roh Kudus, bukan merupakan interpretasi yang tepat dari Alkitab.

Studi tentang Roh Kudus berkembang pesat pada pertengahan abad ke-20 yang beriringan dengan berkembangnya gereja-gereja kharismatik. Fenomena tanda-tanda ajaib atau sering dikenal dengan istilah mujizat terjadi dimana-mana, akan tetapi golongan Injili meyakini bahwa mujizat telah berhenti dilakukan oleh Allah sejak berakhirnya era apostolik atau zaman rasul-rasul. Apa yang semula dikenal sebagai ciri khas dari gerakan Pentakosta secara eksklusif, menjadi milik aliran-aliran lain juga, yang mengalami pekerjaan Roh Kudus yang dinamis di tengah-tengah gereja pada masa itu. Penerapan ajaran mengenai Roh Kudus menimbulkan kontroversi, terkhusus mengenai baptisan Roh Kudus dan tanda-tanda yang mengiringi baptisan tersebut (Rondah, 2006), seperti perdebatan mengenai bahasa lidah yang dipercayai kaum pentakosta sebagai tanda baptisan Roh Kudus. Percakapan dan perdebatan antar teolog dengan berbagai pandangan terus terjadi, termasuk dari sisi aliran Pentakosta. Secara natural diskusi ini mengarah pada kitab Kisah Para Rasul yang menjadi landasan pengajaran tentang baptisan Roh Kudus yang dipegang oleh golongan Pentakosta. Kecenderungan golongan Kharismatik untuk menyatakan bahwa geeja baru dapat disebut bertumbuh apabila anggotanya memiliki pengalaman spektakuler, terutama berbahasa lidah, teologi Alkitab terkadang dinilai lebih rendah bila dibandingkan dengan pengalaman rohani seperti berbahasa lidah (Lukito, 2010). Seiring dengan berkembangnya aliran Pentakosta, bermunculan para advokat sebagai orang-orang yang terlatih secara teologis, sehingga diskusi menjadi lebih berbobot dengan adanya konsensus bahwa penafsiran firman Tuhan dalam hal ini Kisah Para Rasul, harus dilakukan secara bertanggung jawab dengan menerapkan prinsip hermeneutik yang benar (Stott, 2006).

Implikasi Teologis dari peristiwa Pentakosta menuai kritik dari beberapa teolog yang menyatakan bahwa Pentakosta adalah sebuah kejadian yang berulang dari kisah Babel, karena murid-murid pada saat itu berbicara dengan dialek lokal (bukan satu 
bahasa yang sama), dan mereka sekali lagi tersebar di seluruh bumi. Bagaimana seseorang menginterpretasikan peristiwa Pentakosta mempengaruhi misi dan keragaman gereja saat ini. Misalnya, beberapa misionaris Kristen berusaha untuk berasimilasi atau berbicara dengan bahasa dari budaya lain, sementara di sisi lain mempercayai bahwa Kekristenan yang mengglobal akan melampaui perbedaan budaya. Apakah Roh Kudus menghapus perbedaan etnis/ras dan menumbangkan hirarki buatan manusia? Apakah peristiwa Pentakosta menambahkan elemen multietnis yang ramah pada Kekristenan yang harus dirayakan dan ditiru oleh gereja-gereja saat ini? Jika demikian, apakah orang Kristen dewasa ini mengabadikan ideologi bermasalah yang serupa?(Margaret Aymer, Cynthia Briggs Kittredge, 2016).

Berdasarkan hal-hal yang telah dijelaskan di atas, penulis tertarik untuk mengkaji lebih mendalam teks yang menjadi dasar dari perdebatan teologis mengenai topik baptisan dan kepenuhan Roh Kudus dari peristiwa Pentakosta, yaitu Kisah Para Rasul 2: 1-13, dengan menerapkan prinsip-prinsip hermeneutik dalam suatu studi eksegesis. Dengan demikian penulis menetapkan yang menjadi rumusan masalah dalam artikel ini adalah apa makna teologis peristiwa Pentakosta yang ada di Kisah Para Rasul 2: 1-13 dan bagaimana implikasi teologis peristiwa pentakosta dalam Kisah Para Rasul 2: 1-13 pada masa sekarang.

\section{Metode}

Berhubung artikel ini lebih menekankan pada studi eksegesis atau studi tafsir pada ayat Alkitab, maka artikel ini menggunakan metode penelitian kualitatif dengan jenis penelitian kepustakaan (library research). Disebut penelitian kepustakaan karena datadata atau bahan-bahan yang diperlukan dalam menyelesaikan penelitian tersebut berasal dari perpustakaan baik berupa buku-buku, ensiklopedia, kamus, jurnal, serta dokumendokumen pendukung dalam pengambilan data. Secara garis besar ada tiga bidang yang dapat dijadikan objek dalam penelitian kepustakaan, salah satunya adalah bidang kewahyuan, dimana bidang ini memfokuskan pada penelitian terhadap teks-teks kitab suci yang membicarakan tentang masalah tertentu (Harahap, 2014). Dalam hal ini teks kitab suci yang dimaksud adalah Kisah Para Rasul 2: 1-13.

\section{Hasil dan Pembahasan}

\section{Pembahasan Eksegesis Kisah Para Rasul 2:1-13}

Pada ayat 1 tertulis: Ketika tiba hari Pentakosta, semua orang percaya berkumpul di satu tempat ((TB), 2005). Kira-kira jumlahnya sekitar 120 orang pada saat itu, mereka terus berdoa dan memuji selama sepuluh hari setelah kenaikan Yesus, sampai hari Pentakosta yang adalah festival panen di antara orang Yahudi, juga sering disebut Pesta Minggu (Kel 34:22) karena ada satu minggu diantara tujuh minggu dan Paskah. Nubuat Perjanjian Lama dan janji Bapa (diberitakan oleh Yesus, Kisah Para Rasul 1: 4) akan segera digenapi, diantara 120 orang yang masih dalam satu kesepakatan dan semuanya "bersama di satu tempat" dan tidak ada yang hilang. Tidak ada informasi yang pasti mengenai keberadaan tempat itu; tetapi sebagian besar menganggapnya di sebuah ruang 
yang ada di atas dan merupakan markas besar mereka (Kis. 1:13)(Horton, 2001). Mungkin Lukas dengan sengaja membiarkan keterangan lokasi menjadi rancu, karena dia menekankan pentingnya bait suci dan pertemuan rumah. Terutama jika tempat aslinya adalah sebuah rumah, ambiguitasnya memungkinkan bahwa kemungkinan kiasan bait suci pada kata angin yang memenuhi rumah, seperti asap memenuhi rumah Allah dalam Yes 6: 4 (lih. Kis 2: 3; \& Yeh 43: 5). Tetapi sementara kebisingan memenuhi rumah dalam ayat 2 dan orang-orang di dalamnya dipenuhi dengan Roh pada ayat 4, memberi keterangan bahwa mereka seperti berada di Bait Suci kuno (Keener, 2012).

Kata 'hari Pentakosta' merujuk pada hari raya wajib dalam tradisi Yudaisme, yang dipandang sebagai hari diberikannya hukum Allah kepada bangsa Israel di Sinai setelah mereka keluar dari Mesir. Gagasan ini muncul berdasarkan kitab Yoel yang menyebut tentang perayaan Pentakosta sebagai pembaharuan perjanjian Allah dengan Nuh, meskipun kapan persisnya tradisi tersebut berkembang belum diketahui dengan pasti (O’Reilly, 1987). Beberapa pendapat pernah menyebut mengenai referensi tradisi rabinik ini, namun menolaknya dengan alasan bahwa tradisi tersebut berasal dari abad kedua masehi, yang mana hal ini tidak menolong sama sekali untuk menjelaskan gagasan Lukas mengenai hari raya Pentakosta (Menzies, 2005). Bock berpendapat, dalam hal ini Lukas kurang memperhatikan masalah interpretasi hari raya Pentakosta, bagi Lukas hal itu tidak esensial untuk menginterpretasikan tulisannya, ia lebih fokus kepada pokok pembicaraannya mengenai Yesus Kristus yang mencurahkan Roh Kudus, bukan pada makna hari raya Yahudi (Bock, 2012). Pencurahan Roh Kudus yang ajaib pada hari Pentakosta (2: 1-13) memenuhi nubuatan Yesus (Lukas 24:49; Kisah Para Rasul 1: 4-5) dan secara resmi meresmikan komunitas mesianik. Lukas terikat pada tradisi Yahudi: Yahudi Helenistik memberi nama "Pentakosta" ("kelima puluh") untuk "Festival Minggu" Yahudi, yang terjadi lima puluh hari setelah Paskah. Awalnya festival panen, Pentakosta akhirnya merayakan pemberian hukum Musa (Margaret \& Kittredge, 2016).

Ayat 2-3: Tiba-tiba turunlah dari langit suatu bunyi seperti tiupan angin keras yang memenuhi seluruh rumah, dimana mereka duduk; dan tampaklah kepada mereka lidahlidah seperti nyala api yang bertebaran dan hinggap pada mereka masing-masing ((TB), 2005). Kata "tiba-tiba" memberi kesan mengejutkan atau tanpa aba-aba, yang mengacu pada suara yang terdengar dari surga seperti "hembusan angin kencang", atau tornado. Tapi itu bukan angin sungguhan; hanya suaranya yang memenuhi rumah tempat mereka berkumpul, dan hal itu membuat mereka kewalahan, karena suara itu datang "tiba-tiba" dan Lukas menegaskan asal suara itu "dari surga" menyoroti "kontrol ilahi, bukan manusiawi atau atas tindakan Roh." Suara itu tidak diragukan lagi cukup keras untuk menarik perhatian orang banyak yang memenuhi Yerusalem pada saat itu. Suara angin menunjukkan kepada mereka yang hadir bahwa Tuhan akan memanifestasikan dirinya dan Roh-Nya dengan cara yang khusus. Bahwa itu adalah suara angin yang membawa kekuatan akan membuat juga berbicara tentang pemberdayaan yang dijanjikan Yesus dalam Kisah Para Rasul 1: 8, suatu pemberdayaan untuk pelayanan (Horton, 2001).

Banyak penafsir mengaitkan frasa "bunyi seperti tiupan angin keras" dengan kata "angin” yang sering digunakan sebagai lambang Roh Kudus, pendapat ini tidak begitu kuat 
bahkan meragukan karena pada teks ada kata “ $ळ \sigma \pi \varepsilon \rho$ (hōsper/seperti)", sebuah kata penghubung yang bersifat particle comparative (Sutanto, 2006), artinya kata ini menegaskan bahwa angin yang dimaksud hanya sebuah gambaran dan tidak benar-benar ada. Lukas hanya mencari perbandingan yang tepat untuk mendeskripsikan bunyi menderu yang didengar oleh para murid dan orang-orang Yahudi pada saat itu, juga untuk menegaskan bahwa bunyi tersebut adalah tanda yang diberikan oleh Tuhan. O'Reilly melihat pararel antara peristiwa Pentakosta dengan teofani dalam peristiwa Sinai, terlihat jelas dalam bahasa yang digunakan Lukas dalam Kisah Para Rasul 2. Para teolog

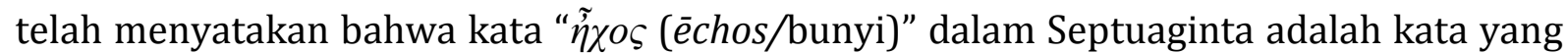
mengacu pada teofani (bnd Kel. 19:6). Kata “ $\pi v o \tilde{\eta} \varsigma$ (pnoēs/angin kencang)" juga adalah elemen tradisional untuk teofani menurut Targum dan naskah-naskah Yahudi lainnya (O’Reilly, 1987).

Mungkin saja Lukas melihat kesesuaian simbolis antara pencurahan Roh Kudus dengan perayaan pada abad pertama bagi kaum Yudaisme yaitu teofani di gunung Sinai (Barton \& Muddiman, 2007). Lukas lebih memilih untuk memakai kata " $\pi v o \tilde{\eta} \varsigma$ (pnoēs/ angin kencang)" dibanding dengan kata " $\pi v \varepsilon \tilde{v} \mu \alpha$ (pneuma/angin)", karena Lukas ingin mengarahkan pembacanya pada fenomena teofani, bukan pada Roh Kudus. Bagi Lukas, Roh Kudus bukanlah sekedar kekuatan yang digambarkan dengan angin kencang, melainkan Tuhan sendiri yang hadir menyatakan diri-Nya di tengah umat (Witherington, 1998). Penting untuk diperhatikan bahwa Lukas mencatat "turunlah dari langit suatu bunyi..." yang mengindikasikan pengalaman transenden dan juga secara spasial dapat dilihat dan dirasakan: dari atas turun ke bawah. Roh itu turun dari luar tubuh dan secara imanen berdiam di dalam para murid, menimbulkan manifestasi fisik yang terlihat juga. Hal ini penting karena pengalaman akan Roh itu semakin intens dirasa dalam lingkup ruang dan waktu yang temporal (Pradipta, 2020). Dalam hal ini Lukas merupakan penulis yang berhati-hati dan penuh perhatian dalam menyampaikan setiap gagasan pada katakata yang dipilih.

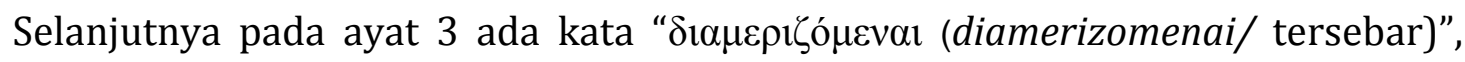
menurut Lightfoot kata ini selalu diartikan dengan gambaran seperti orang yang sedang diperhadapkan di sebuah persidangan (lih. Kis 4:7), pengertian ini juga ditunjukkan oleh kata-kata simbolis dari bagian tersebut, yaitu lidah-lidah seperti nyala api, yang tegasnya bukanlah api sungguhan (Lightfoot, 2014), sama dengan penjelasan pada ayat 2, ada kata penghubung sejenis yang bersifat particle comparative (Sutanto, 2006), yaitu kata " $\omega \sigma \varepsilon i ̀$ (hōsei/seperti)." Bagian peristiwa pada ayat 2 merupakan pengalaman pendengaran dan pengalaman visual pada ayat 3 tentang teofani yang sering terjadi dalam kisah Alkitab, penekanannya lebih pada perbandingan terhadap deskripsi dari yang berlangsung pada saat itu, baik angin dan api selalu dikaitkan dengan pernyataan diri Allah. Tetapi pilihan dari dua gambaran ini sangat tepat untuk melambangkan kedatangan Roh. Kata 'angin' dalam bahasa Ibrani maupun Yunani, terkait erat dengan 'roh', gambar 'api' merupakan metafora 'bahasa roh' seperti yang dinyatakan pada ayat 3, jelas sangat berhubungan dengan fakta bahwa hasil dari manifestasi kuasa ilahi ini adalah ucapan yang diilhami pada ayat 4 (Barton \& Muddiman, 2007). 
Mengenai "lidah-lidah api", Barret menjelaskan bahwa kata "lidah" yang digunakan di sini harus berarti (dalam kontras yang mengejutkan dengan ay. 4) sesuatu yang berbentuk seperti lidah; Lukas mungkin memaksudkan bahwa satu nyala api seperti lidah bertumpu pada setiap orang. Api kadang-kadang dikatakan telah bertumpu pada kepala para rabi saat mereka mempelajari atau memperdebatkan tentang Taurat, tetapi baik pemikiran tentang kehadiran ilahi yang bertumpu pada orang-orang saleh maupun gambar api tidak secara khas Semit atau alkitabiah. Sangat mungkin bahwa Lukas melihat dalam peristiwa ini sebagai penggenapan prediksi Pembaptis (Luk. 3:16), meskipun cara itu awalnya merujuk pada penghakiman dengan angin dan api (Barrett, 2002).

Ayat 4: Maka penuhlah mereka dengan Roh Kudus, lalu mereka mulai berkata-kata dalam bahasa-bahasa lain, seperti yang diberikan oleh Roh itu kepada mereka untuk mengatakannya (TB, 2005). Pada ayat 2 tercatat sebuah suara "memenuhi" rumah tempat para murid berdoa dan pada ayat ini para murid "dipenuhi" dengan Roh lalu menghasilkan jenis suara yang berbeda, dimana lebih lanjut dijelaskan pada ayat 6. Frasa "penuh dengan Roh Kudus" adalah frasa yang disukai oleh Lukas. Ia menggunakan frasa itu tidak kurang dari sembilan kali sepanjang Injil dan Kisah Para Rasul. Dalam hal ini Stronstad mencatat beberapa hal penting, yaitu: 1) frasa penuh dengan Roh Kudus digunakan berdasarkan penggunaan dalam Perjanjian Lama, 2) memiliki makna yang sama dengan Injil Lukas, dan 3) memiliki makna yang berbeda dengan tulisan Paulus dalam surat kepada jemaat di Efesus (Stronstad, 2012).

Bahasa Lukas disini sangat mudah dimengerti bahkan oleh beberapa orang bukan Yahudi yang tidak terpelajar sekalipun. Karena seseorang yang diilhami untuk berbicara secara otoritatif kepada dewa sebanding dengan seseorang yang "penuh dengan keilahian." Namun Lukas berbagi dengan para pendengarnya yang berlatar belakang umum, yang lebih sentral dalam Alkitab. Dalam Alkitab, frasa "dipenuhi dengan Roh" diterapkan pada pemberian Roh untuk keterampilan, baik dalam keahlian suci (Kel. 31: 3; 35:31), untuk kepemimpinan (Ulangan 34: 9), atau untuk nubuatan (Mik. 3: 8). Lukas sering menggunakan frase "dipenuhi dengan Roh", terutama untuk pengalaman yang memungkinkan para nabi dan inspirasi kenabian (Lukas 1:15, 41, 67) dan untuk kekuatan pemberitaan Kristen, baik untuk para rasul (Kis. 4: 8; 9: 17; 13: 9) dan lainnya (4:31; 13:52). Narasi ini mendemokrasikan pengisian nubuatan Roh yang tersebar luas dalam Bil. 11: 16-17, 25 lebih jauh lagi, memenuhi doa Musa agar semua umat Allah akan dipenuhi dengan Roh (Bil. 11:29). Beberapa penafsir Yahudi kemudian juga menghubungkan Bilangan 11:29 dengan Yoel 2:28, menunjukkan bahwa pencurahan Yoel merupakan jawaban dari doa Musa. Lukas juga menggunakan ungkapan terkait "penuh dengan Roh, "mungkin untuk menggambarkan mereka yang sudah atau secara teratur diperlengkapi oleh Roh untuk tugas-tugas mereka (Lukas 4: 1; Kis. 6: 3, 5; 7:55; 11:24)(Keener, 2012).

Dalam Kisah Para Rasul 1: 8 menyatakan bahwa apa yang dimulai sedang berlanjut, hal ini menunjukkan bahwa berbicara dalam bahasa lain adalah iringan normatif dari baptisan Roh Kudus dan hal itu terus menjadi pemberian yang mendatangkan peneguhan dan berkah pada kesempatan yang lain. Perkataan ini datang 


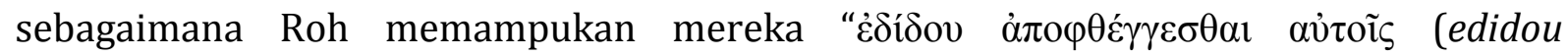
apophthengesthai autois/melanjutkan memberi dan terus memberi mereka untuk berbicara dengan lantang dan berani)," yaitu dengan menggunakan lidah mereka, otot mereka; mereka berbicara. Namun, kata-katanya tidak datang dari pikiran atau pemikiran mereka sendiri. Roh memberi mereka apa yang harus mereka bicarakan dan diungkapkan dengan berani, lantang, dan dengan urapan dan kuasa yang jelas. Ini adalah satu-satunya tanda baptisan Roh Kudus yang diulangi (Horton, 2001).

Dunn menyatakan bahwa Roh Kudus yang terjadi pada hari pentakosta ini adalah klimaks dari pelayanan Yesus. Pelayanan yang dimaksud adalah pelayanan Yesus bagi diri-Nya yang mencapai klimaks pada kenaikan-Nya ke surga, namun pelayanan Yesus bagi murid-murid-Nya berpuncak pada pencurahan Roh Kudus. Bahkan kematian dan kebangkitan Yesus sama sekali tidak berdampak apa-apa bila Roh Kudus tidak dicurahkan. Dengan kata lain, baptisan Roh Kudus pada hari Pentakosta tidak berhubungan dengan pengutusan maupun pemberdayaan, Dunn mengakui adanya unsur pemberdayaan, namun ia menyatakan bahwa hal itu bukan fokus dari pencurahan Roh Kudus, melainkan sebuah manifestasi kuasa dari karya keselamatan Yesus bagi muridmurid-Nya dan inisiasi era yang baru (Dunn, 2016).

Tidak ada indikasi bahwa keselamatan para murid belum sempurna ataupun bahwa pencurahan Roh Kudus adalah klimaks dari pelayanan Yesus. Lukas secara jelas menegaskan 'kuasa' yang diberikan dengan tujuan memperlengkapi para murid menjadi saksi Yesus. Stronstad berpendapat bahwa tujuan dari pencurahan Roh Kudus pada hari Pentakosta bukanlah penyempurnaan dari pekerjaan keselamatan oleh Kristus, melainkan sebuah tugas misi. Janji pemberian kuasa sebagai manifestasi dari Roh adalah jaminan bagi para murid bahwa Yesus tidak akan membiarkan mereka dengan kemampuan mereka sendiri. Sebaliknya, mereka akan diperlengkapi sepenuhnya untuk tugas mereka sebagai saksi. Bahkan, mereka akan menerima kuasa yang sama dengan apa yang diterima Yesus pada saat menjalankan misi-Nya di dunia. Jadi, pada intinya Lukas mendeskripsikan Roh Kudus yang dijanjikan oleh Yesus tidak identik dengan keselamatan, akan tetapi dengan pemberdayaan dengan kuasa, pencurahan Roh Kudus adalah pencurahan kuasa atas umat Tuhan untuk menjadi saksi-Nya (Stronstad, 2012).

Ayat 5-13: Waktu itu di Yerusalem diam orang-orang Yahudi yang saleh dari segala bangsa di bawah kolong langit. Ketika turun bunyi itu, berkerumunlah orang banyak. Mereka bingung karena mereka masing-masing mendengar rasul-rasul itu berkata-kata dalam bahasa mereka sendiri. Mereka semuanya tercengang-cengang dan sangat termangu-mangu sambil berkata seorang kepada yang lain: "Apakah artinya ini?" Tetapi orang lain menyindir: Mereka sedang mabuk oleh anggur manis (TB, 2005).

Bagian ini merupakan sebuah adegan dimana murid-murid yang berbicara dalam bahasa lain oleh ilham Roh yang terbuka secara langsung ke dalam pembicaraan orang banyak yang mengenali bahasa-bahasa ini dan bahwa para rasul menginjili melalui kesamaan bahasa mereka. Bagian ini juga menawarkan daftar lokasi pendengar yang beragam secara bahasa (Keener, 2012). Ayat 5 menunjukkan beberapa variasi yang dapat disimpulkan dari pengamatan bahwa kata 'orang Yahudi' dan 'saleh' tidaklah pasti. Orang- 
orang Yahudi mungkin masuk sebagai catatan pengecualian yang dimaksudkan untuk menunjukkan bahwa orang-orang saleh adalah orang-orang Yahudi berdasarkan agama meskipun berdasarkan ras atau tempat tinggal mereka adalah Partia, Media, dan lain-lain. Sebaliknya, orang-orang Yahudi mungkin telah dianggap tidak sesuai dengan Partia, Media, dan lain-lain. Lukas sedang memikirkan kumpulan besar orang-orang Yahudi yang terbaik, paling saleh, dan cenderung paling disukai, berkumpul di Yerusalem untuk pesta atau untuk tinggal secara permanen (Barrett, 2002).

Frasa "dari semua bangsa di bawah langit" adalah ekspresi idiom yang berarti "dari banyak tempat," atau dari semua bangsa di mana orang Yahudi diserakkan (MacArthur, 2015). Menanggapi frasa yang sama, Bock menyatakan bahwa penggunaan frasa ini tidak hanya melukiskan keragaman etnis orang-orang yang menyaksikan peristiwa itu, namun juga secara geografis dimana mereka secara kebetulan datang dari luar daerah ke Yerusalem (Bock, 2012). Di satu sisi, Yerusalem adalah pusat kosmopolitan di mana banyak orang Yahudi yang sudah tersebar ke segala daerah di luar Palestina datang

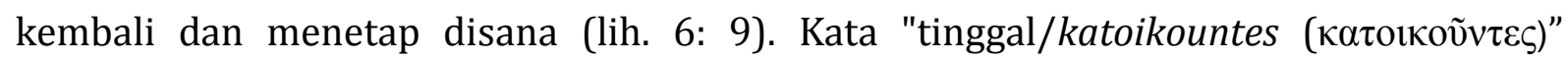
biasanya berarti sesuatu yang lebih dari sekedar tinggal atau berkunjung sementara. Bagaimanapun, karena itu adalah Hari Raya Pentakosta salah satu dari tiga pesta yang diharuskan oleh tradisi untuk hadir di Yerusalem (Ulangan 16:16) dapat diyakini bahwa mungkin sebanyak satu juta orang Yahudi dari seluruh penjuru yang dikenal dunia berada di Yerusalem. Mereka adalah orang-orang yang taat dan takut akan Tuhan, tulus dalam menyembah Tuhan. Mungkin lebih banyak dari mereka akan berada di Yerusalem saat itu daripada saat Paskah, karena perjalanan di Laut Mediterania lebih aman pada musim itu (Horton, 2001).

Witherington memberi penjelasan bahwa pada intinya frasa ini tidak sedang membicarakan peziarah yang datang ke Yerusalem dari tempat persebaran mereka hanya untuk merayakan Pentakosta. Namun orang Yahudi Diaspora yang telah datang untuk menetap di Yerusalem, dan tentunya mereka juga beribadah di sinagoga-sinagoga yang didirikan oleh orang-orang Yahudi Diaspora di Yerusalem (lih. Kis. 6:9) (Witherington, 1998). Para penonton yang menyaksikan peristiwa itu adalah orang Yahudi Diaspora yang taat yang tinggal di Yerusalem (2: 5). Ini adalah contoh pertama dalam Kisah

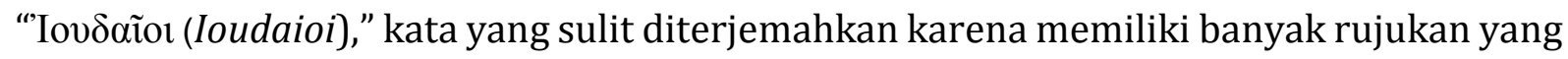
tumpang tindih: geografis, agama, dan etnis. Daftar negara berikutnya (2: 9-11) mirip dengan daftar yang ditemukan dalam astrologi kuno dan tulisan sejarah. Para sarjana telah mengusulkan beberapa sumber langsung (misalnya Kej. 10 dan Kedutaan Besar Philo untuk Gayus 281-82). Selain pertanyaan tentang terjemahan dan turunan, penjajaran 'Iovdaĩo (Ioudaioi) dan daftar negara di awal Kisah Para Rasul memperkuat pesan Lukas bahwa Injil datang pertama kali kepada orang-orang Yahudi, kemudian menyebar ke seluruh dunia (Margaret Aymer, Cynthia Briggs Kittredge, 2016). Ternyata terdapat dua kelompok besar bangsa yang dipersatukan masing-masing oleh bahasa sehari-hari yang berbeda. Menurut para ahli kelompok pertama adalah orang-orang Yahudi perantauan yang berbicara dengan bahasa Aram; mereka adalah keturunan Yahudi yang pernah terbuang ke tanah Asyur. Sementara itu, kelompok kedua adalah 
orang-orang Yahudi yang merantau ke arah Barat Palestina, yang berbicara dengan bahasa Yunani. Maksud dengan "bahasa-bahasa lain" pada ayat 4 adalah bahasa-bahasa yang dipakai oleh orang-orang Yahudi perantauan dalam kehidupan sehari-hari, yaitu Aram dan Yunani (Adiprasetya, 2020).

Selain audiens yang menyaksikan peristiwa pada saat itu, ada hal yang lebih menarik lagi untuk ditelaah lebih mendalam yaitu ekspresi mereka. Reaksi orang-orang Yahudi ditekankan kembali oleh Lukas, apa yang mereka lihat dan dengar membuat mereka sangat kebingungan, terutama karena mereka tidak bisa menjelaskan fenomena yang sedang terjadi pada saat itu. Mereka semua bingung karena masing-masing mendengar para murid yang 120 orang itu berbicara dalam bahasa mereka sendiri. Kata " ióía (idia/sendiri)" adalah empatik, dalam artian bahasanya sendiri yang dia gunakan sejak lahir, akan tetapi bahasa lidah disini adalah bahasa yang berbeda, para murid tidak hanya berbicara dalam berbagai dialek Galilea atau Aram tetapi dalam berbagai bahasa yang sama sekali berbeda. Hasilnya di antara para pendengar benar-benar takjub, mereka tercengang. Mereka dipenuhi dengan keajaiban yang membuat mereka terpesona, karena mereka mengenali bahwa 120 orang (mungkin dari pakaian mereka) adalah orang Galilea dan mereka tidak bisa mengerti bagaimana mereka bisa mendengar bahasa negara asal mereka digunakan oleh orang Galilea (Horton, 2001).

Orang Galilea memiliki logat atau aksen yang khas, bisa dikatakan "kasar" dalam pengucapannya memakai bahasa Aram, dan mungkin logat atau aksen tersebut terbawa ketika mereka berbicara pada hari Pentakosta, pada intinya orang-orang ini bukanlah orang-orang yang mahir dalam berbahasa yang baik. Bock menggarisbawahi frasa

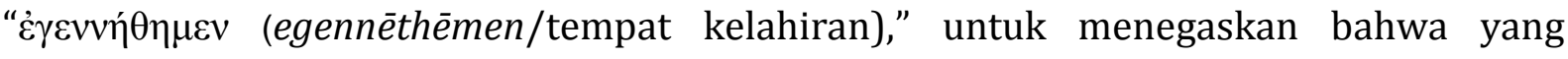
dimaksud adalah bahasa asal atau bahasa ibu orang-orang itu. Tuhan memakai alat bahasa yang paling akrab dengan setiap kelompok bangsa untuk memastikan bahwa pesan itu sampai kepada pendengarnya dalam bentuk yang mengena bagi mereka (Bock, 2012). Orang-orang Galilea yang dimaksud telah dikemukakan bahwa berhubungan erat dengan orang-orang saleh pada ayat 5, tetapi Lukas di sini tertarik pada bahasa, bukan kesalehan mereka, mungkin juga pada tingkat pendidikan yang diharapkan Lukas dari orang-orang Galilea (Barrett, 2002).

Dalam bahasa Yunani menunjukkan ada gerakan serta kata-kata yang mengejek para murid pada saat itu, mereka dianggap seperti beberapa orang pemabuk yang menimbulkan kebisingan dan ini mungkin yang dipikirkan para pencemooh saat itu. Hal ini tidak boleh dibiarkan, jangan mengira ada tanda-tanda kegilaan seperti pesta pora para pemabuk kafir, pencela-pencela itu salah. Emosi utama para murid masih berupa kegembiraan. Mereka telah berterima kasih dan memuji Tuhan dalam bahasa mereka sendiri (Luk. 24:53); dan sekarang Roh Kudus telah memberi mereka bahasa-bahasa baru untuk memuji Tuhan. Dapat diyakini bahwa dari 120 hati mereka masih mengarah kepada Tuhan untuk memuji pekerjaan-Nya yang luar biasa, meskipun mereka tidak mengerti apa yang mereka bicarakan (Horton, 2001). 


\section{Makna Teologis Peristiwa Pentakosta Dalam Kisah Para Rasul 2: 1-13}

Sesuai dengan pertanyaan pada rumusan permasalahan di pendahuluan mengenai apa makna peristiwa Pentakosta dalam teks Kisah Para Rasul 2: 1-13 dan berdasarkan studi eksegesis yang penulis telah lakukan terhadap teks yang dimaksud, maka penulis menyimpulkan yang menjadi makna peristiwa Pentakosta adalah sebagai berikut:

Momen pencurahan Roh Kudus sebagai penggenapan janji Allah. Berdasarkan ruang lingkup dan naskah pada perikopnya sendiri, jelas nampak bahwa pencurahan Roh Kudus yang terjadi pada hari Pentakosta merupakan penggenapan nubuat Perjanjian Lama terutama kitab nabi Yoel. Menurut penulis, hal yang perlu dicermati kembali adalah bahwa pencurahan Roh Kudus yang terjadi pada hari Pentakosta bukan penanda awal dari era yang baru, karena era Roh Kudus telah dimulai bersama dengan era Mesianik dan terus berlanjut hingga akhir zaman.

Petrus dengan tegas menyatakan bahwa pencurahan Roh Kudus seperti yang terjadi atas para murid pada hari Pentakosta, bersifat paradigmatik bagi semua orang yang percaya kepada Yesus Kristus (Kis. 2:39). Secara historis tentu Pentakosta tidak dapat diulangi; namun esensi dari peristiwa ini, yaitu pencurahan Roh Kudus, terus tersedia bagi orang-orang percaya dalam segala zaman. Kisah Para Rasul sendiri membuktikan bahwa Roh Kudus masih terus dicurahkan bagi orang-orang yang percaya kepada Yesus, tanpa terbatas kebangsaan atau status sosial mereka. Semua peristiwa pencurahan Roh Kudus yang terjadi dalam Kisah Para Rasul merupakan kelanjutan dari peristiwa Pentakosta, yang merupakan awal penggenapan janji Allah untuk mencurahkan Roh-Nya atas semua manusia. Karena "hari-hari terakhir" yang disebutkan Petrus masih terus berlanjut hingga hari Tuhan datang, Roh Kudus akan terus dicurahkan bagi setiap generasi, atas setiap orang yang percaya kepada Yesus.

Tuhan telah mengakui Gereja sebagai Bait Suci baru, hal berikutnya adalah mencurahkan Roh Kudus ke atas anggota Tubuh. Apa yang Yesus janjikan sebagai baptisan digambarkan disini sebagai isian, yaitu pengalaman yang penuh dan memuaskan. Beberapa mencoba membuat perbedaan antara dibaptis dengan Roh Kudus dan dibasahi. Sebenarnya, Alkitab menggunakan berbagai macam istilah. Itu juga merupakan pencurahan Roh seperti yang dinubuatkan Yoel (Kis. 2: 17-18, 33); menerima (dan secara aktif menerima) hadiah (Kis. 2:38); jatuh di atas (Kis. 8:16); pencurahan karunia (Kis .10:45); dan yang akan datang. Dengan variasi istilah ini tidak mungkin untuk menganggap bahwa baptisan berbeda dengan pengisian. Ingat juga, karena Roh Kudus adalah Oknum, jelas bahwa berbicara mengenai pengalaman yang membawa kepada suatu hubungan. Setiap istilah memunculkan beberapa aspek atau pengalaman Pentakosta, dan tidak ada istilah yang dapat memunculkan semua aspek dari pengalaman itu (Keener, 2012).

Momen pencurahan Roh Kudus adalah penggenapan janji mengenai Kuasa Roh Kudus sebagai pemberdayaan untuk menjadi saksi Yesus Kristus. Dalam struktur Lukas dan Kisah Para Rasul, narasi peristiwa Pentakosta berdiri dalam hubungan yang sama dengan Kisah Para Rasul seperti yang dilakukan narasi masa kanak-kanak Yesus dalam Injil. Narasi-narasi ini tidak hanya memperkenalkan motif yang mendefinisikan misi 
Yesus, tetapi juga menunjukkan bahwa Yesus akan melaksanakan misinya dengan kuasa Roh Kudus, seperti yang tercantum pada Kisah Para Rasul 1: 8. Dengan cara yang sama, narasi peristiwa Pentakosta memperkenalkan baik misi para murid di masa depan dengan pemberdayaan Roh yang saling melengkapi. Narasi peristiwa Pentakosta adalah kisah transfer Roh karismatik dari Yesus kepada para murid. Dengan kata lain, setelah menjadi pembawa Roh Kudus secara eksklusif pada baptisannya, Yesus menjadi pemberi Roh pada hari Pentakosta (Stronstad, 2012).

Tujuan dari pencurahan Roh Kudus sendiri adalah pemberdayaan dengan kuasa atas mereka yang percaya kepada Yesus untuk menjadi saksi-Nya (Luk. 24:49; Kis. 1:8). Lukas tidak menjadikan peran soteriologis Roh Kudus sebagai sebuah atribut dalam konteks ini, tidak juga dalam khotbah Petrus untuk menjelaskan fenomena Pentakosta kemudian. Sebaliknya, peran Roh Kudus dalam pemberdayaan adalah krusial hingga murid-murid dilarang meninggalkan Yerusalem sebelum mereka menerima kuasa yang akan diberikan Roh Kudus kepada mereka (Luk. 24:49; Kis. 1:4-5). Lukas memiliki alasan penting untuk menekankan bahasa roh ketika mengemas kedatangan Roh. Penekanan khusus Lukas mengenai Roh adalah pemberdayaan untuk kesaksian nubuatan lintas budaya (Kis. 1: 8), dan tidak ada yang lebih baik untuk melambangkan pemberdayaan dalam melewati rintangan seperti itu selain kemampuan untuk berbicara, melalui ilham Roh, dalam konteks ayat ini adalah bahasa yang belum dipelajari seseorang (Keener, 2012). Berdasarkan tanda-tanda yang menyertai peristiwa Pentakosta kuasa yang dimaksud oleh Yesus sebagai pemberdayaan meliputi keberanian dan kecakapan untuk berbicara tentang keselamatan di dalam Yesus Kristus kepada orang banyak. Muridmurid Yesus membayangkan otoritas politik namun yang Yesus adalah pembaharuan spiritual (1:8). Pada narasi berikutnya dalam Kisah Para Rasul kuasa yang diberikan oleh Roh Kudus juga memampukan murid-murid Yesus untuk mengadakan mujizat. Semua hal itu memiliki satu tujuan, yaitu meyakinkan orang-orang yang mendengar kesaksian mereka bahwa Yesus sungguh-sungguh adalah Tuhan.

\section{Implikasi}

Sehubungan dengan rumusan masalah yang kedua mengenai bagaimana implikasi teologis peristiwa Pentakosta dalam Kisah Para Rasul 2: 1-13 di masa sekarang, penulis mendeskripsikannya sebagai berikut. Implikasi teologis peristiwa Pentakosta bagi gerejagereja aliran Pentakosta adalah menjadikan peristiwa Pentakosta sebagai acuan dasar pengajaran mengenai baptisan Roh Kudus. Mengutip pendapat Menzies dari sebuah jurnal yang menyatakan bahwa ada dua arti penting berbahasa roh bagi orang Pentakosta di seluruh dunia. Pertama, berbicara dalam bahasa roh menyoroti, mewujudkan, dan mengafirmasi cara unik orang-orang Pentakosta memahami Kisah Para Rasul, dimana kitab itu bukan hanya berisi dokumen sejarah, melainkan menyajikan model kehidupan gereja masa kini. Dapat dikatakan, bahasa roh berfungsi sebagai tanda bahwa pengalaman gereja mereka adalah pengalaman yang berlaku untuk gereja masa kini. Kedua, bahasa roh mengingatkan gereja untuk mengenali dan mengingat identitas gereja sebagi komunitas yang dipanggil sebagai nabi akhir zaman dan diberi kuasa untuk menjadi saksi 
yang berani bagi Yesus. Singkatnya, bagi kaum Pentakosta, bahasa roh berfungsi sebagai tanda bahwa panggilan dan kuasa gereja rasuli berlaku bagi orang percaya masa kini (Kalis \& Panjaitan, 2020).

Beberapa teolog menyatakan bahwa Pentakosta adalah sebuah kejadian yang berulang dari kisah Babel, karena murid-murid pada saat itu berbicara dengan dialek lokal (bukan satu bahasa yang sama), dan mereka sekali lagi tersebar di seluruh bumi. Persoalannya terletak pada bagaimana seseorang menginterpretasikan peristiwa Pentakosta, sehingga dampaknya dapat mempengaruhi misi dan keragaman gereja saat ini (Aymer \& Kittredge, 2016). Dalam konteks yang sejajar, Adiprasetya pernah menanggapi pertanyaan seorang jemaat yang bertanya kepadanya mengenai hal bahasa lidah, mengapa di 'gereja mereka' (bukan aliran Pentakosta) tidak diterapkan berbahasa lidah dalam liturgi ibadah. Namun Joas menjabarkan dalam bukunya mengenai teori diglossia, dimana teori ini menegaskan bahwa hampir setiap orang mempergunakan dua bahasa, yaitu bahasa yang tinggi dan rendah. Bahasa tinggi sering dipergunakan dalam peristiwa resmi, sedangkan yang rendah dipergunakan sehari-hari (Adiprasetya, 2020). Dalam konteks peristiwa Pentakosta, bahasa Ibrani adalah bahasa tinggi karena dipergunakan dalam ibadah, tetapi peristiwa itu terjadi bukan di rumah ibadah melainkan di rumah biasa, hal ini menunjukkan bahwa ketika Roh Kudus dicurahkan dan mulai menggerakkan para murid untuk berbicara dalam bahasa-bahasa lain, bahasa itu adalah bahasa sehari-hari atau bahasa rendah. Hal ini menguatkan pendapat Bock yang menyatakan bahwa frasa "egennēthēmen" (tempat kelahiran), berguna untuk menegaskan bahwa yang dimaksud adalah bahasa asal atau bahasa ibu orang-orang itu. Tuhan memakai alat bahasa yang paling akrab dengan setiap kelompok bangsa untuk memastikan bahwa pesan itu sampai kepada pendengarnya dalam bentuk yang mengena bagi mereka (Bock, 2012).

Lanjutan dari penjabaran Adiprasetya mengenai bahasa lidah, ia mengarahkan perhatian pembacanya tertuju pada frasa "seperti yang diberikan oleh Roh itu kepada mereka untuk mengatakannya," Adiprasetya menjelaskan bahwa Roh Kudus diberikan kepada murid agar mereka mengatakan kebenaran. Ketika Roh Kudus memberikan otoritas dan kuasa kepada seseorang untuk menyatakan kebenaran, maka apa yang diucapkan oleh orang itu tetap muncul "dengan akal yang sehat." Dengan kata lain, terjadi sinergi antara karunia berkata-kata dari Roh Kudus dan pikiran yang jernih dari orang tersebut. Maka, ketika itu terjadi, apa pun yang keluar dari mulut orang itu akan sungguhsungguh menjadi sebuah "bahasa lidah." Apa yang supernatural adalah Roh Kudus itu sendiri, yang bekerja melalui cara-cara natural dan manusiawi, melalui bahasa sehari-hari (Adiprasetya, 2020). Mendukung penjabaran ini, Keener menyatakan bahwa tidak ada yang lebih baik untuk melambangkan pemberdayaan dalam melewati rintangan, selain kemampuan untuk berbicara, melalui ilham Roh (Keener, 2012).

\section{Rekomendasi untuk Penelitian Lanjutan}

Penulis menyadari keterbatasan penulis dalam melakukan studi eksegesis pada teks Kisah Para Rasul 2: 1-13, maka dari itu penulis menyarankan bagi para rekan se- 
profesi khususnya para dosen-dosen bidang teologi biblika kiranya berkenan memberikan sumbangsih pemikiran dengan melakukan penelitian lebih lanjut terkait topik baptisan Roh Kudus yang dalam hal ini penulis mengangkat peristiwa pentakosta pada teks Kisah Para Rasul 2: 1-13. Penulis berharap dengan banyaknya kajian penelitian mengenai baptisan Roh Kudus, semakin memperkaya referensi gereja terkait doktrin Roh Kudus.

\section{Kesimpulan}

Berdasarkan rumusan masalah mengenai makna peristiwa Pentakosta dalam Kisah Para Rasul 2: 1-13, dan berdasarkan hasil dari pembahasan eksegesis teks Kisah Para Rasul 2: 1-13, didapati ada dua pemaknaan mengenai peristiwa Pentakosta, yaitu: Pertama, peristiwa Pentakosa adalah momen pencurahan Roh Kudus sebagai penggenapan janji Allah, baik dari apa yang dicatat oleh Yoel maupun dari yang Yesus katakan kepada para murid ketika Ia naik ke Sorga. Kedua, peristiwa Pentakosta adalah momen pencurahan Roh Kudus adalah penggenapan janji mengenai Kuasa Roh Kudus sebagai pemberdayaan untuk menjadi saksi Yesus Kristus. Penelitian ini juga bertujuan untuk mengetahui implikasi teologis peristiwa Pentakosta dalam Kisah Para Rasul 1: 113. Dimana peristiwa Pentakosta sangat penting bagi gereja-gereja aliran pentakosta dan kharismatik, maka dari itu tidak heran mereka memberi penekanan mengenai esensi peristiwa ini, yaitu pencurahan Roh Kudus yang terus tersedia bagi orang-orang percaya dalam segala zaman. Karena Kisah Para Rasul sendiri membuktikan bahwa Roh Kudus masih terus dicurahkan bagi orang-orang yang percaya kepada Yesus, tanpa terbatas kebangsaan atau status sosial mereka. Namun, bagi gereja-gereja di luar aliran Pentakosta bukan berarti peristiwa ini tidak penting, akan tetapi mereka hanya memberikan penekanan yang berbeda, lebih mengarah pada bagaimana hal-hal terkait peristiwa Pentakosta seperti baptisan dan bahasa Roh Kudus dapat dimaknai dan menjadi relevan dalam kehidupan sehari-hari.

\section{Rujukan}

A. T. B. (2005). Kisah Para Rasul 2. Lembaga Alkitab Indonesia.

Adiprasetya, J. (2020). Labirin Kehidupan: Spiritualitas Sehari-hari Bagi Peziarah Iman. BPK Gunung Mulia.

Barrett, C. K. (2002). Acts of the Apostles: A Shorter Commentary. T\&T Clark.

Bock, D. L. (2012). A Theology of Luke and Acts: God's Promised Program, Realized for All Nations. Zondervan.

Cole, S. J. (2013). Lesson 4: The Meaning of Pentecost (acts 2:1-13). Bible.Org. https://bible.org/seriespage/lesson-4-meaning-pentecost-acts-21-13

Dunn, J. D. G. (2016). The Acts of The Apostles (Eerdmans E). William B. Eerdmans Publishing Company.

Harahap, N. (2014). Penelitian Kepustakaan. Jurnal Iqra', 08(1), 68-73.

Horton, S. M. (2001). ACTS: A Logion Press Commentary (electronic). LOGION Press. John Barton \& John Muddiman (Ed.). (2007). The Oxford Bible Commentary. Oxford 
University Press.

Keener, C. S. (2012). ACTS An Exegetical Commentary: Introduction And 1:1-2:47 Volume 1. Baker Academic.

Lightfoot, J. B. (2014). The Acts of the Apostle: A Newly Discovered Commentary Volume 1 (Ben Witherington III and Todd D. Still (Ed.)). InterVarsity Press.

Lukito, D. L. (2010). Baptisan dan Kepenuhan Roh: Sebuah Perbandingan Antara Pandangan Kekinian Dengan Data Kisah Para Rasul. Veritas: Jurnal Teologi Dan Pelayanan, 11(1), 97-110.

MacArthur, J. (2015). The MacArthur New Testament Commentary-The Complete Set 33 Volumes (Electronic). Moody Press.

Margaret Aymer, Cynthia Briggs Kittredge, D. A. S. (Ed.). (2016). The Gospels and Acts: Fortress Commentary On The Bible Study Edition. Fortress Press.

Menzies, R. P. (2005). Empowered for Witness: The Spirit In Luke Acts. T\&T Clark.

O'Reilly, L. (1987). Word and Sign in the Acts of the Apostles. Loyola Press.

Pew Research. (2011). Global Christianity-A Report on the Size and Distribution of the world's Christian Population. https://www.pewresearch.org/

Pradipta, D. A. (2020). Peristiwa Pentakosta Dipandang Dari Perspektif Teologi Yang Transformatif. Matheo : Jurnal Teologi/Kependetaan, 10(1), 12-22. https://doi.org/10.47562/matheo.v10i1.98

Rondah, D. (2006). Kepenuhan Roh Kudus. Jurnal Jaffray, 4(1), 30. https://doi.org/10.25278/jj71.v4i1.131

Stevanus, Kalis : Panjaitan, F. (2020). Baptisan Roh Kudus dalam Perspektif Pentakostal. Logia : Jurnal Teologi Pentakosta, 2(2), 1-21.

Stott, J. R. W. (2006). Baptism and Fullness: The Work of The Holy Spirit Today. InterVarsity Press.

Stronstad, R. (2012). The Charismatic Theology of St. Luke (Kedua). Baker Academic.

Sutanto, H. (2006). Perjanjian Baru Interlinear Yunani-Indonesia dan Korkondansi Perjanjian Baru (PBIK). Lembaga Alkitab Indonesia.

Witherington, B. (1998). The Acts of the Apostles: A Socio-Rhetorical Commentary. Wm. B. Eerdmans Publishing. 